\title{
The Seasonal Variation of Light Nonmethane Hydrocarbons in the Antarctic Troposphere
}

\author{
J. Rudolph, A. KHEDim, AND D. WAGenBaCH ${ }^{1}$
}

\author{
Institut für Atmospharische Chemie Kernforschungsanlage Jülich, Federal Republic of Germany
}

\begin{abstract}
About 80 samples of antarctic air were collected between 1982 and 1985 at the "Georg von Neumayer" station $\left(70^{\circ} 36^{\prime} \mathrm{S}\right.$ and $\left.8^{\circ} 22^{\prime} \mathrm{W}\right)$ and analyzed for ethane, ethene, acetylene, propane, and propene. Yearly average mixing ratios were $0.37,0.36,0.011,0.07$, and $0.21 \mathrm{ppb}$, respectively. The seasonal cycles for ethane and acetylene showed minima around the late southern hemispheric summer and maxima in late winter. The phase of the seasonal cycle in ethane and acetylene can be explained by seasonal variation of atmospheric removal rates. Seasonal variation of one of the major southern hemispheric ethane and acetylene sources, biomass burning, would cause a similar seasonal change. Propane exhibits a much higher variability and shows no clear seasonal cycle. The atmospheric mixing ratios of ethene and propene peak around early austral fall and are most probably mainly determined by seasonal variation in emissions from the oceans surrounding Antarctica.
\end{abstract}

\section{INTRODUCTION}

In past years it has been recognized that light nonmethane hydrocarbons (NMHC) may be important to the chemistry of the unpolluted troposphere. Due to their high rate constants for the reaction with $\mathrm{OH}$ radicals, these compounds are significant in atmospheric photochemical reaction cycles in spite of their rather low abundance in the atmosphere [e.g., Rudolph and Ehhalt, 1981; Rudolph et al., 1982; Singh and Salas, 1982; Rudolph, 1988; Fishman and Carney, 1984]. Still, knowledge of the longitudinal, latitudinal, and seasonal distribution of these species is limited. The seasonal variation of atmospheric mixing ratios of light NMHC is especially poorly known. The few published measurements of the seasonal dependence of some light NMHC do not yet present a comprehensive and consistent picture [Singh and Salas, 1982; Tille et al., 1985; Blake and Rowland, 1986]. Only for ethane is there available a somewhat more comprehensive set of measurements at different seasons at remote locations [Blake and Rowland, 1986]. NMHC are emitted from a number of different types of sources, and their average atmospheric lifetimes range from several months to less than 1 day [cf. Ehhalt and Rudolph, 1984]. Consequently, all measurements of NMHC will be strongly influenced by local and regional sources, and thus any interpretation of systematic or seemingly unsystematic variations must consider the possible impact of this. Unfortunately, neither the NMHC emission rates nor the various factors which affect them are yet really known. To minimize these problems, we decided to make a series of NMHC measurements over Antarctica, a remote area where only a small number of research stations provide minimal human influence. The only known significant hydrocarbon sources in or near Antarctica are emissions from the surrounding oceans.

\footnotetext{
'Now at Institut für Umweltphysik, Universität Heidelberg, Federal Republic of Germany.

Copyright 1989 by the American Geophysical Union.

Paper number 89JD01096.

0148-0227/89/89JD-01096\$05.00
}

\section{EXPERIMENT}

Between 1982 and 1985, about 80 air samples were collected near the "Georg von Neumayer" station in Antarctica. The station is located at $70^{\circ} 36^{\prime} \mathrm{S}$ and $8^{\circ} 22^{\prime} \mathrm{W}$ close to the Atka Bay, about $7 \mathrm{~km}$ away from the ice edge. The air samples were collected in evacuated stainless steel containers $\left(2 \mathrm{dm}^{3}\right)$ equipped with metal bellows valves. A detailed description of the sample canisters and their preparation is given by Rudolph et al. [1981]. Laboratory tests confirmed that air samples can be stored in these containers for more than 1 year without detectable change in their mixing ratios of $\mathrm{C}_{2}$ and $\mathrm{C}_{3}$ hydrocarbons. Some of the sample canisters were returned to the laboratory empty. These were filled with purified synthetic air and then analyzed for light NMHC. No significant levels of light NMHC could be detected in these test samples. Furthermore, several of the Antarctic samples were analyzed a second time about 6 months after the first analyses. Although the precision of this second analysis was, as a result of the smaller available sample volume, not as good as the first measurement, both measurements agreed with each other to better than $\approx 25 \%$. No systematic increase or decrease could be seen.

The samples were collected about once every 2 weeks outside and upwind from a clear air laboratory about $1.5 \mathrm{~km}$ south of the station. The short sampling times necessary for collecting grab samples allowed us to select meteorological conditions (wind speed and direction) w'ich essentially eliminate the possibility of any contamination by hydrocarbon emissions from the station itself. The clean air laboratory is equipped with a condensation particle counter, which was used to verify that the air samples were collected under clean air conditions, free of pollution influences. Details of the clean air laboratory and its location are described by Wagenbach et al. [1988]. Their results show that under such conditions, even for measurements which require very long sampling periods (e.g., filter sampling for trace elements), in general, uncontaminated samples are obtained. The air samples were shipped back to the laboratory once each year for analysis. The measurements were made by gas chromatography in combination with a cryogenic preconcentration step [Rudolph and Jebsen, 1983]. The lower limits of detection for $C_{2}$ and $C_{3}$ hydrocarbons were around $10 \mathrm{ppt}$ by volume. 


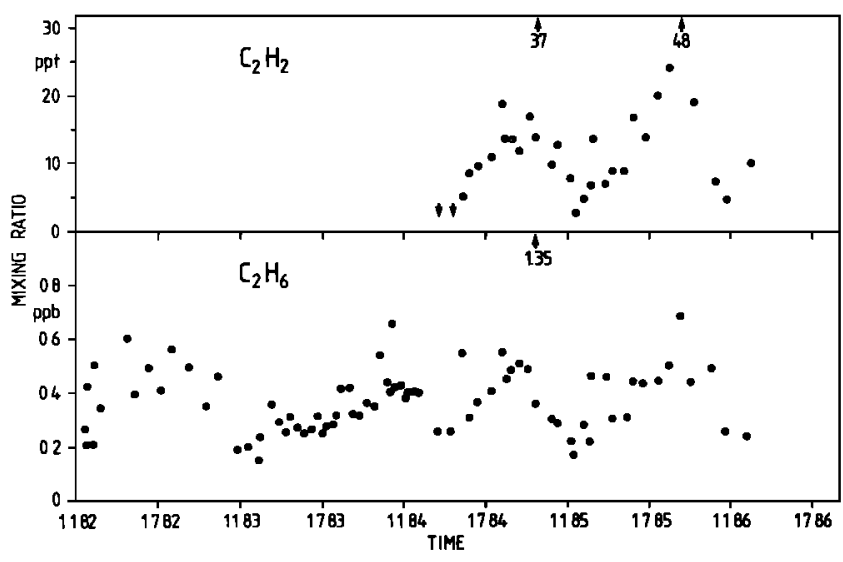

Fig. 1. Atmospheric ethane and acetylene mixing ratios over Antarctica between 1982 and 1985.

This allowed measurements of ethane, ethene, propane, and propene with sufficient accuracy and reliability. However, the mixing ratios of acetylene were often below the lower limit of detection and very seldom more than twice the detection limit. The samples collected after 1983 were analyzed by an improved gas chromatographic technique (for a detailed description, see Rudolph et al. [1986]). This improved the lower limit of detection for acetylene in the air samples to less than $5 \mathrm{ppt}$. The reproducibility of the measurements was better than $10 \%$ for mixing ratios well above the lower limit of detection. The uncertainty for measurements of mixing ratios below 20 ppt may reach $30 \%$. The absolute concentrations were obtained by comparison with an air sample of known content of light NMHC. This standard was calibrated with mixtures of the individual hydrocarbons in synthetic air. These mixtures were prepared by a three-step static dilution of the pure substances with purified synthetic air. The NMHC mixing ratios in the calibration gases are in the range of several tenths to a few parts per billion. The linearity of the measuring technique was confirmed by further diluting air samples down to levels of a few ppt NMHC. All measurements are based on the same absolute calibration. The stability of the standard was checked by comparison with newly prepared mixtures in intervals of roughly 1 year. The accuracy of the calibration is estimated to be about $20 \%$.

\section{RESUlTS AND Discussion}

The measured ethane and acetylene mixing ratios are plotted as a function of time in Figure 1. The data show considerable scatter, but a significant seasonal cycle is visible. The individual data for ethene, propene, and propane would not allow the recognition of any systematic seasonal cycle. Therefore we averaged the monthly NMHC mixing ratios over all 4 years to improve the signal from the systematic seasonal variation. These averages and their mean standard deviations are shown in Figures $2 a-2 e$. Each monthly average contains about seven measurements, except for acetylene, where the number of measurements is about 3-4 for each average. As can be expected from the limited number of data, the monthly averaged mixing ratios of the $\mathrm{C}_{2}$ and $\mathrm{C}_{3}$ hydrocarbons have considerable uncertainties. Still, there are clear indications for the existence of systematic seasonal cycles.

The atmospheric residence times for $C_{2}$ and $C_{3}$ hydrocarbons can be estimated from published reaction rate constants, measured $\mathrm{O}_{3}$ concentrations, and $\mathrm{OH}$ radical concentrations from model calculations. Table 1 shows the atmospheric lifetimes of $\mathrm{C}_{2}$ and $\mathrm{C}_{3}$ hydrocarbons for different latitudes and seasons. There are published estimates of the total global source strength for light NMHC [Ehhalt and Rudolph, 1984], but there is still considerable uncertainty in these estimates. Probably the largest continental sources for light NMHC in the southern hemisphere are biomass burning and emissions from plants. Engine exhaust, natural gas losses, and other industrial NMHC sources are of considerably less importance in the southern hemisphere than in the northern hemisphere. The only land areas located south of $40^{\circ} \mathrm{S}$ are southern Patagonia, Tasmania, and the South Island of New Zealand. These areas are rather small, sparsely populated, and not industrialized. Thus essentially all emissions from continental areas will be from latitudes north of $40^{\circ} \mathrm{S}$.

Emissions from oceans can significantly contribute to the NMHC levels over remote oceans [cf. Rudolph and Ehhalt, 1981; Bonsang et al., 1988; Bonsang and Lambert, 1984]. Lamontagne et al. [1974] report for the Pacific a strong increase in concentration of light NMHC in seawater near the ice-covered region of Antarctica, probably the result of high primary productivity in the nutrient-rich oceans surrounding Antarctica.

Neither the NMHC emission rates nor their seasonal

TABLE 1. Average Atmospheric Photochemical Lifetimes (d, day, $y r$, year) of $\mathrm{C}_{2}$ and $\mathrm{C}_{3}$ Hydrocarbons at Different Latitudes

\begin{tabular}{|c|c|c|c|c|c|c|}
\hline \multirow[b]{2}{*}{ Compound } & \multicolumn{2}{|c|}{$45^{\circ} \mathrm{S}$} & \multicolumn{2}{|c|}{$60^{\circ} \mathrm{S}$} & \multicolumn{2}{|c|}{$70^{\circ} \mathrm{S}$} \\
\hline & January & July & January & July & January & July \\
\hline Ethane & $60 \mathrm{~d}$ & $240 \mathrm{~d}$ & $2.5 \mathrm{yr}$ & $17 \mathrm{yr}$ & $5 \mathrm{yr}$ & $*$ \\
\hline Propane & $12 \mathrm{~d}$ & $45 \mathrm{~d}$ & $175 \mathrm{~d}$ & $2.8 \mathrm{yr}$ & $0.9 \mathrm{yr}$ & $*$ \\
\hline Ethene & $2 \mathrm{~d}$ & $4 \mathrm{~d}$ & $14 \mathrm{~d}$ & $25 \mathrm{~d}$ & $26 \mathrm{~d}$ & $70 \mathrm{~d}$ \\
\hline Propene & $0.6 \mathrm{~d}$ & $1.2 \mathrm{~d}$ & $3 \mathrm{~d}$ & $4.5 \mathrm{~d}$ & $5.5 \mathrm{~d}$ & $8 d$ \\
\hline Acetylene & $21 \mathrm{~d}$ & $75 \mathrm{~d}$ & $270 \mathrm{~d}$ & $4.2 \mathrm{yr}$ & $1.3 \mathrm{yr}$ & $*$ \\
\hline
\end{tabular}

Lifetimes are calculated from the reaction rate constants of the hydrocarbons with OH radicals [Atkinson, 1984; Hampson and Garvin, 1978; Michael et al., 1980] and the $\mathrm{OH}$ radical concentrations modeled by Volz et al. [1981]. For ethene and propene the reaction with $\mathrm{O}_{3}$ is also taken into account (rate constants from Atkinson [1984]; $\mathrm{O}_{3}$ concentrations from Routhier et al. [1980] and Oltmans and Komhyr, [1986]).

*No photochemical removal for this time of the year and latitude. 
variation is known for the oceanic regions around Antarctica. However, there is some indirect information which allows us to roughly predict the seasonality of these emissions. From the extreme summer-winter contrast in the solar radiation at high latitudes, we can expect a higher biological productivity for austral summer. Also, the ice coverage of the oceans around Antarctica has its minimum between January and April [Schwerdtfeger, 1970]. It seems reasonable to assume that a larger ice coverage of the oceans in the vicinity of the measuring station would reduce the emission rates of biogenic trace gases from the oceans. Indeed, nonsea-salt sulfate ("excess sulfate") concentrations in the atmosphere at Neumayer station peak around late austral summer and early fall [Wagenbach et al., 1988]. Since nonsea-salt sulfate in the remote marine atmosphere is primarily formed from organosulfur compounds of marine origin [Andreae, 1986], this supports our assumptions of maximum biogenic emissions around early austral fall.

There are some indirect pieces of evidence regarding atmospheric transport to Antarctica. The seasonal cycle of crustal material [cf. Wagenbach et al., 1988] and of ${ }^{222} \mathrm{Rn}$ [Polian et al., 1986; Lambert et al., 1970], both tracers of continental origin, shows highest concentrations over Antarctica during southern hemispheric summer. This indicates that the exchange with lower latitudes is faster during austral summer than winter.

For the reactive, rather short-lived alkenes, transport from continents or lower latitudes is an unlikely explanation of their substantial atmospheric mixing ratios observed at Neumayer station. Their atmospheric lifetimes at $45^{\circ}$ and below of a few days or less are too short (cf. Table 1). Consequently, emissions from the oceans at high latitudes are most probably the source of the ethene and propene mixing ratios measured over Antarctica. Our ethene and propene data show a large nonsystematic variability which can be expected for trace gases of short atmospheric residence time. Still, our data indicate that the levels of ethene and propene peak in southern hemispheric autumn. This agrees with our assumption of a predominantly oceanic origin of ethene and propene. Furthermore, the ratio of the ethene to propene concentration is rather constant, on the average $1.7 \pm 0.3$. This is within the range of published estimates for oceanic emissions [Rudolph and Ehhalt, 1981; Ehhalt and Rudolph, 1984; Bonsang et al., 1988] of 0.9-2.1 (ethene/propene on a volume per volume basis). This indicates that the observed ethene and propene mixing ratios are predominantly the result of oceanic emissions and dilution of these emissions by transport. Similar observations were made by Bonsang et al. [1988] over other ocean areas at lower latitudes which were considered to be strong sources of light NMHC. The only other published alkene measurements over Antarctica are the ethene mixing ratios from the South Pole in the Antarctic summer published by Khalil and Rasmussen [1986]. The average of these values from the interior of Antarctica for the years $1979-1985$ is $74 \mathrm{ppt}$, about one third our average summer values at Neumayer station, which is located near the coast of Antarctica.

Ethane is one of the longest lived NMHC. With an average global atmospheric residence time of 2 months and much longer lifetimes at high latitudes (cf. Table 1), we can expect that exchange between Antarctica and lower latitudes determines the ethane mixing ratios we observed over Antarctica. In Table 2 our Antarctic ethane data are compared with other published measurements from the southern hemisphere. Most of the data agree within their uncertainties, very well, with our Antarctic data. The average ratio of all the southern hemispheric ethane measurements and our Antarctic data for the same month (average of 4 years) is 0.88 with a standard deviation of 0.3 . The average from the measurements at middle and low southern latitudes is 0.32 ppb; the yearly average of our Antarctic ethane measurements is $0.37 \mathrm{ppb}$. This difference of $15 \%$ includes all uncertainties due to analytical errors and, since many of the measurement series are based on independent calibrations, also differences in the absolute calibration of the various measurement series. Therefore it is justified to assume that on the average, our Antarctic measurements agree with the southern hemispheric average ethane mixing ratios at lower latitudes.

Khalil and Rasmussen report time series measurements of ethane at the South Pole between the beginning of October 1984 and middle of January 1985 which show a decrease very similar to the change we observed for the same period (cf. Figure 1). They report a decrease from about $310 \mathrm{ppt}$ in mid-October to about $120 \mathrm{ppt}$ in mid-January. On the average our data for this period are roughly 20-25\% higher (360 ppt in mid-October, $165 \mathrm{ppt}$ in mid-January) but show exactly the same relative decrease.

The ethane data in Figure 1 exhibit considerable scatter, but a systematic seasonal cycle is still clearly visible. Lowest mixing ratios of roughly $200 \mathrm{ppt}$ are found in December, January, and February. The highest values around 500 ppt in general occur between July and October. On the average the seasonal change (Figure 2) is about $50 \%$ between the January minimum and the August/September maximum. This systematic seasonal cycle is highly significant.

Blake and Rowland [1986] made measurements of the seasonal cycle of ethane at high northern latitudes. They observed the highest atmospheric ethane mixing ratios around February and the lowest values in July/August. Compared with our Antarctic measurements, this seasonal cycle of ethane is shifted by 6 months, representing exactly the difference in season between the northern and southern hemisphere.

Under the assumption that the ethane emission rates are approximately constant, seasonal variation of the atmospheric lifetimes would cause a seasonal cycle with maxima in austral winter and minima in summer. However, biomass burning (agricultural waste burning, bush fires, and deforestation) in the southern hemisphere occurs mainly during July-October. Thus that source and its seasonal variation would also contribute to a seasonal cycle of atmospheric ethane, with the highest mixing ratios in late austral winter. The southern hemispheric seasonal variability of oceanic emissions and microbial production of ethane is essentially unknown. Due to the relatively low energy consumption and level of industrialization in the southern hemisphere, we can rule out engine exhaust, natural gas losses, or industrial emissions as dominant sources for ethane in the southern hemisphere. Thus both factors, the seasonal dependence of emissions and the seasonal variability of atmospheric removal rates, can explain the observed ethane cycle with maxima in winter and minima in summer. Propane has similar sources but an atmospheric lifetime of a factor of 5 shorter than ethane. Thus the much larger variability in the propane mixing ratios is not surprising (Figure $2 b$ ). Pub- 
TABLE 2. Comparison of Antarctic Ethane Measurements With Published Southern Hemispheric Ethane Data

\begin{tabular}{|c|c|c|c|c|c|}
\hline Location & Reference & $\begin{array}{l}\text { Latitude } \\
\text { Range, } \\
{ }^{\circ} \mathrm{S}\end{array}$ & Date & $\begin{array}{c}\mathrm{C}_{2} \mathrm{H}_{6} \\
\mathrm{ppb}\end{array}$ & $\begin{array}{c}\text { Antarctic } \\
\text { Monthly } \\
\text { Mean } \\
\text { Over } 4 \\
\text { Years, } \\
\text { ppb }\end{array}$ \\
\hline $\begin{array}{c}\text { South Pole, } \\
\text { sea level }\end{array}$ & $\begin{array}{l}\text { Khalil and } \\
\text { Rasmussen } \\
\text { [1986] }\end{array}$ & 90 & $\begin{array}{l}\text { Austral } \\
\text { summer } \\
1979-1985\end{array}$ & 0.163 & $0.31 \pm 0.5$ \\
\hline $\begin{array}{l}\text { Pacific, sea } \\
\text { level }\end{array}$ & $\begin{array}{l}\text { Blake and } \\
\text { Rowland } \\
{[1986]}\end{array}$ & $10-47$ & March 1985 & $0.14 \pm 0.07$ & $0.33 \pm 0.04$ \\
\hline $\begin{array}{l}\text { Atlantic, } \\
\text { sea level }\end{array}$ & $\begin{array}{l}\text { Rudolph et al. } \\
{[1982]}\end{array}$ & $0-70$ & $\begin{array}{l}\text { March } 1981 \\
\text { April } 1981\end{array}$ & 0.5 & $0.34 \pm \mathbf{0 . 0 6}$ \\
\hline $\begin{array}{l}\text { Atlantic } \\
2-11 \mathrm{~km}\end{array}$ & $\begin{array}{c}\text { Ehhalt et al. } \\
{[1984]}\end{array}$ & $10-60$ & $\begin{array}{l}\text { April } 1980 \\
\text { May } 1980\end{array}$ & $0.3-0.5$ & $0.36 \pm 0.05$ \\
\hline $\begin{array}{l}\text { Pacific, } \\
\text { above } \\
\text { sea level }\end{array}$ & $\begin{array}{l}\text { Rasmussen } \\
\text { and Khalil } \\
{[1982]}\end{array}$ & $10-60$ & May 1978 & 0.38 & $0.36 \pm 0.04$ \\
\hline $\begin{array}{l}\text { Pacific, sea } \\
\text { level }\end{array}$ & $\begin{array}{l}\text { Blake and } \\
\text { Rowland } \\
\text { [1986] }\end{array}$ & $10-47$ & June 1985 & $0.28 \pm 0.04$ & $0.35 \pm 0.04$ \\
\hline $\begin{array}{l}\text { Atlantic, } \\
\quad 1-11 \mathrm{~km}\end{array}$ & $\begin{array}{r}\text { Rudolph } \\
{[1988]}\end{array}$ & $\begin{array}{l}30-50 \\
50-60\end{array}$ & $\begin{array}{l}\text { June } 1984 \\
\text { June } 1984\end{array}$ & $\begin{array}{l}0.3-0.5 \\
0.2-0.3\end{array}$ & $\begin{array}{l}0.35 \pm 0.04 \\
0.35 \pm 0.04\end{array}$ \\
\hline $\begin{array}{l}\text { Pacific, sea } \\
\text { level }\end{array}$ & $\begin{array}{l}\text { Blake and } \\
\text { Rowland } \\
{[1986]}\end{array}$ & $10-47$ & Sept. 1984 & $0.35 \pm 0.11$ & $0.46 \pm 0.07$ \\
\hline $\begin{array}{l}\text { Pacific, sea } \\
\text { level }\end{array}$ & $\begin{array}{c}\text { Bonsang and } \\
\text { Lambert } \\
{[1984]}\end{array}$ & $5-35$ & Nov. 1982 & 0.4 & $0.44 \pm 0.04$ \\
\hline $\begin{array}{l}\text { Pacific, } \\
\text { above } \\
\text { sea level }\end{array}$ & $\begin{array}{l}\text { Aikin ef al. } \\
\text { [1982] }\end{array}$ & $10-60$ & Nov. 1976 & 0.2 & $0.44 \pm 0.04$ \\
\hline $\begin{array}{l}\text { Pacific, sea } \\
\text { level }\end{array}$ & $\begin{array}{l}\text { Singh and } \\
\quad \text { Salas [1982] }\end{array}$ & $0-32$ & Dec. 1981 & $0.29-0.23$ & $0.33 \pm 0.04$ \\
\hline $\begin{array}{l}\text { Pacific, sea } \\
\text { level }\end{array}$ & $\begin{array}{l}\text { Blake and } \\
\text { Rowland } \\
\text { [1986] }\end{array}$ & $10-47$ & Dec. 1984 & $0.3 \pm 0.09$ & $0.33 \pm 0.04$ \\
\hline
\end{tabular}

lished measurements of propane in the marine atmosphere of the southern hemisphere [Singh and Salas, 1982; Rudolph et al., 1982; Bonsang and Lambert, 1984; Ehhalt et al., 1985; Rudolph, 1988] range around 0.1 ppb but vary by a factor of about 4 with no apparent systematic trend with season or latitude. Our Antarctic data also do not show pronounced systematic changes with season. Only the propane mixing ratios found from January to March are significantly lower than the yearly average of $0.07 \mathrm{ppb}$, and only the atmospheric propane mixing ratios in August and September are significantly higher. Considering the large nonsystematic variability of the propane mixing ratios and the limited number of measurements, we cannot yet assign these changes to a representative, systematic seasonal cycle.

The average global atmospheric lifetime of acetylene is about 3 weeks, considerably longer than the lifetime of propane but still by nearly a factor of 3 shorter than the average atmospheric lifetime of ethane. The sources of acetylene differ considerably from those for the alkanes and alkenes. Engine exhaust and biomass burning are the main acetylene sources. Recently, Kanakidou et al. [1988] documented evidence that oceans can be weak acetylene sources, however, probably by more than an order of magnitude lower than for the other $\mathrm{C}_{2}$ and $\mathrm{C}_{3}$ hydrocarbons. Our atmospheric acetylene mixing ratios of 5-15 ppt over Antarctica are a factor of 5-10 lower than published data from lower southern latitudes [Rasmussen and Khalil, 1982; Ru- dolph et al., 1982; Singh and Salas, 1982; Ehhalt et al., 1985; Rudolph, 1988]. A decrease of the acetylene mixing ratios toward higher latitudes is also indicated by the measurements of Rudolph [1988]. Our measurements (Figure 1) show considerable unsystematic scatter. Part of the variability is due to analytical errors, since the lower acetylene values around $0.005 \mathrm{ppb}$ are close to the lower limit of detection for acetylene. Still the data indicate the existence of a significant seasonal cycle with lowest mixing ratios around 5 ppt in January, February, and March and highest values of $15 \mathrm{ppt}$ between August and October.

As mentioned before, other tracers for continental air masses, mineral dust particles, and ${ }^{222} \mathrm{Rn}$ show their highest concentrations over Antarctica during local summer [ $\mathrm{Wa}$ genbach et al., 1988; Polian et al., 1986; Lambert et al., 1970]. This indicates that the exchange between lower latitudes and Antarctica is enhanced during this time. Since the seasonal cycle of acetylene over Antarctica shows a minimum during austral summer, other factors must be responsible for the observed seasonality. More effective removal of acetylene during transport from lower latitudes due to the higher $\mathrm{OH}$ radical concentrations in summer can explain the observed minima during austral summer. Also, one of the main acetylene sources, biomass burning, has its maximum during southern hemispheric winter and can thus be responsible for the observed seasonal variability of acetylene. 


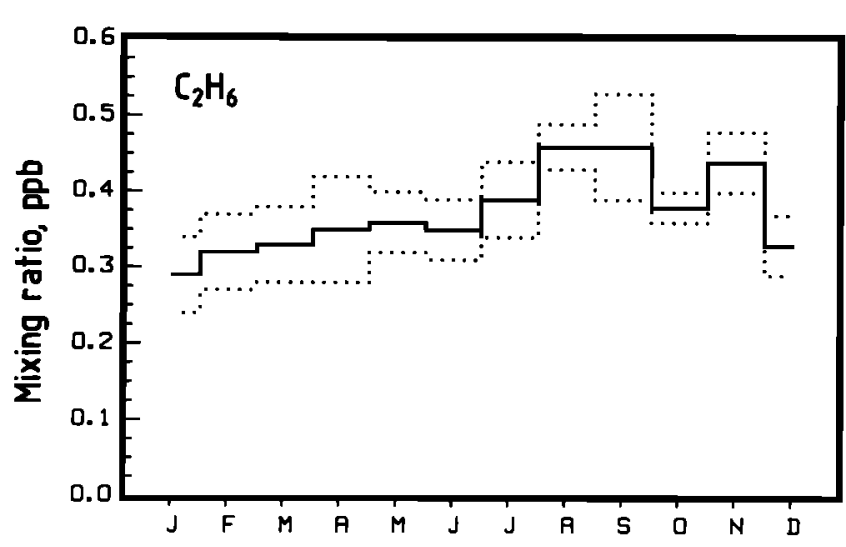

Fig. $2 a$

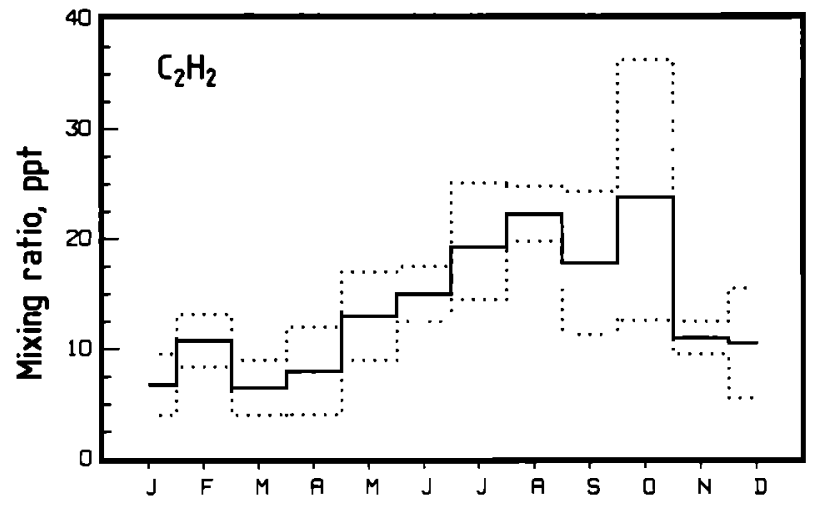

Fig. 2c

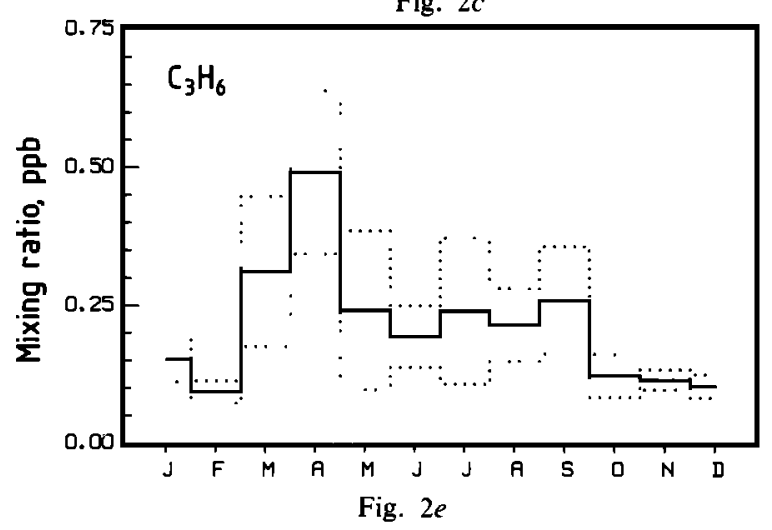

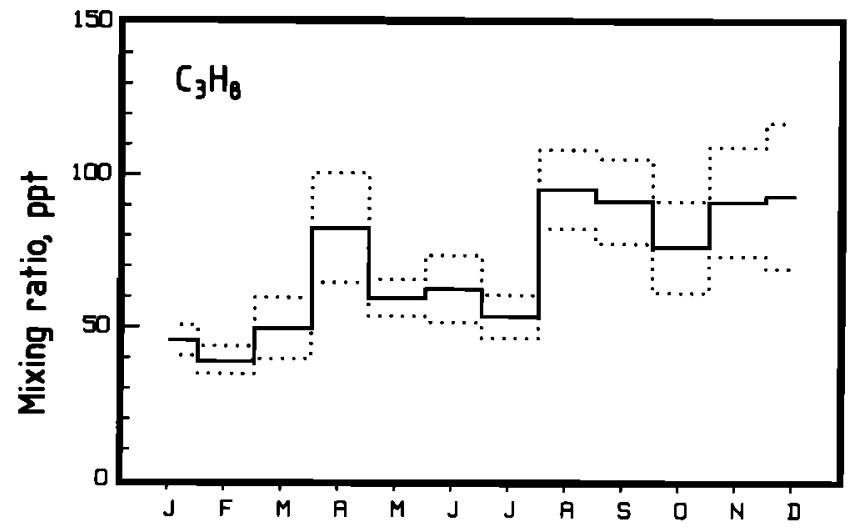

Fig. $2 b$

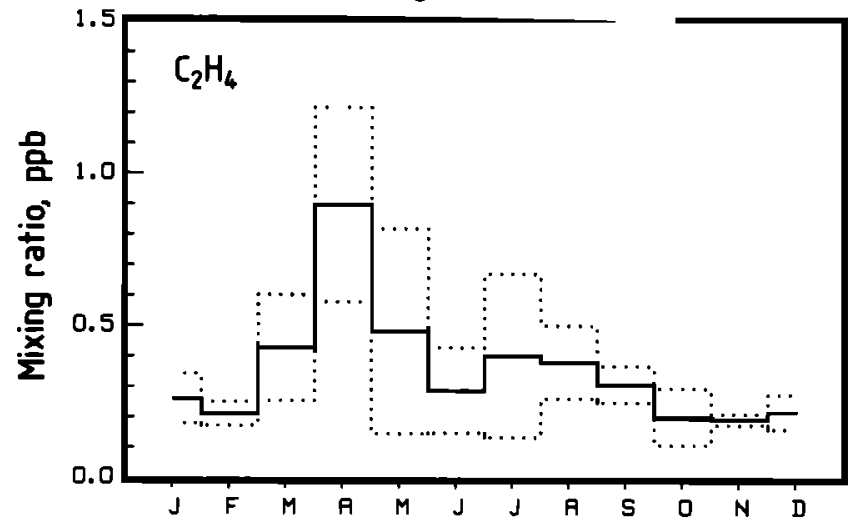

Fig. $2 d$

Fig. 2. Averaged seasonal cycle of $\mathrm{C}_{2}$ and $\mathrm{C}_{3}$ hydrocarbon mixing ratios over Antarctica. (a) Ethane, (b) propane, (c) acetylene, $(d)$ ethene, and $(e)$ propene. Solid line, mean values; dotted line, mean \pm error of mean.

\section{Conclusion}

The seasonal cycles of the individual hydrocarbons over Antarctica are governed by different factors. For the relatively short-lived light alkenes, emission from the oceans surrounding Antarctica is probably the dominating source. With yearly average mixing ratios of $0.36 \mathrm{ppb}$ of ethene and $0.21 \mathrm{ppb}$ of propene, the light alkenes are, due to their high photochemical reactivity, important components for the photochemical reaction cycles at high southern latitudes. As far as reactions with $\mathrm{OH}$ radicals are concerned, the light alkenes contribute about $50 \%$ of the reactions with methane to the photochemical reaction cycles in the Antarctic atmosphere. Since the alkenes also react with ozone, this estimate is rather conservative. Moreover, under conditions with low atmospheric $\mathrm{OH}$ radical concentrations (high latitudes, winter), the dominant removal mechanism for alkenes is the reaction with ozone; thus the light alkenes probably have a significant impact on atmospheric chemistry at high southern latitudes.

Ethane has a yearly average atmospheric mixing ratio of $0.37 \mathrm{ppb}$ over Antarctica, comparable in magnitude with ethene and propene. The ethane mixing ratios observed over Antarctica seem to be reasonably representative for the southern hemisphere. On the average, atmospheric ethane measurements over Antarctica agree within a nonsystematic variability of $30 \%$ with data from lower latitudes in the southern hemisphere. The observed seasonal cycle for ethane can be explained by seasonal variation of the atmospheric removal rate, but also the seasonal dependence of one of the major southern hemispheric ethane sources, biomass burning, agrees in phase with the observed seasonal cycle of ethane.

Acetylene has a similar seasonal cycle; however, the yearly average acetylene mixing ratio of $0.011 \mathrm{ppb}$ is much 
smaller. Due to its shorter atmospheric lifetime, the Antarctic acetylene mixing ratios are, on the average, significantly below values from lower latitudes. This indicates that the dominant southern hemispheric acetylene sources are loc.' ed at low latitudes. Probably the most important southern hernispheric acetylene source is biomass burning.

Although the presented measurements of $C_{2}$ and $C_{3}$ hydrocarbons over Antarctica already give some insight into their seasonal variability, the overall picture is far from being complete. Due to the limited number of measurement points, the calculated monthly mean values still have substantial uncertainties. We are continuing our NMHC measurements at the Georg von Neumayer station to reduce the uncertainties in our knowledge of their seasonal cycles at high southern latitudes. Also measurements in other regions of Antarctica would be valuable in order to improve our understanding of the atmospheric chemistry, sources, and sinks of light NMHC at high southern latitudes. The remoteness of Antarctica offers a nearly unique possibility to study the seasonal changes of light NMHC with a minimum of local impact. Consequently, measurements of light NMHC together with tracers for the extent of continental influence (e.g., ${ }^{222} \mathrm{Rn}$, mineral dust, soot particles) should considerably improve our understanding of the southern hemispheric cycles of light NMHC.

Acknowledgments. The authors thank the Alfred-WegenerInstitut and all members of the staff of the Georg von Neumayer station for the collection of the samples at the station. This work was unported financially by the minister for research and technology of the Federal Republic of Germany

\section{REFERENCES}

Aiken, A. C., J. R. Herman, E. J. Maier, and C. J. McQuillan, Atmospheric chemistry of ethane and ethylene, J. Geophys. Res., $87,3105-3118,1982$.

Andreae, M. O, The ocean as a source of atmospheric sulfur compounds, in The Role of Alr-Sea Exchange in Geochemical Cycling, NATO ASI Ser. C, vol. 185, edıted by P. Buat-Menard, pp. 331-361, D. Reidel, Hingham, Mass., 1986.

Atkınson, R, Evaluation of kinetic and mechanistic data for mod eling of photochemical smog, J. Phys. Chem. Ref. Data, 13, $315-344,1984$.

Blake, D. R., and F. S Rowland, Global atmospheric concentrations and source strength of ethane, Nature, 32l, 231-233, 1986.

Bonsang, B., and $\mathrm{G}$ Lambert, Nonmethane hydrocarbons in an oceanic atmosphere, J. Atmos. Chem., 2, 257-271, 1984.

Bonsang, B., M. Kanakidou, G. Lambert, and P. Monfray, The marine source of $\mathrm{C}_{2}-\mathrm{C}_{5}$ alıphatic hydrocarbons, J. Atmos. Chem., 6, 3-20, 1988.

Ehhalt, D. H., and J. Rudolph, On the importance of light hydrocarbons in multiphase atmospheric systems, Ber. Kernforschungsanlage Jülich, $J \dot{U} L-1942,1984$.

Ehhalt, D. H., J. Rudolph, F. X. Meixner, and U. Schmidt, Measurements of selected $C_{2}-C_{5}$ hydrocarbons in the background troposphere: Vertical and latitudinal variations, J. Atmos. Chem., $3,29-52,1985$.

Fishman, J., and T. A. Carney, A one-dimensional photochemical model of the troposphere with planetary boundary layer parameterization, J. Atmos. Chem., I, 351-376, 1984.

Hampson, R. F., and D. Garvin (Eds.), Reaction rate and photochemical data for atmospheric chemistry 1977, Natl. Bur. Standards Spec. Publ., 513, 1978.

Kanakidow, M., B. Bonsang, J. C. Le Roulley, G. Lambert, D. Martin, and G. Sennequier, Marine source of atmospheric acetylene, Nature, 333, 51-52, 1988.

Khalil, M. A. K., and R. A. Rasmussen, Temporal variability of $\mathrm{C}_{2}$-hydrocarbons at the South Pole: Seasonal cycles and the possible effects of El-Nino, Antarct. J. U.S., 21(5), 244-245, 1986.
Lambert, G., G. Polian, and D. Toupin, Existence of periodicity in radon concentrations and in the large-scale circulation at lower altitudes between $40^{\circ}$ and $70^{\circ}$ south, J. Geophys. Res., 75, 2341-2345, 1970.

Lamontagne, R. A., J. W. Swinnerton, and V. J. Linnenbom, $\mathrm{C}_{1}-\mathrm{C}_{4}$ hydrocarbons in the North and South Pacific, Tellus, 26, 71-77, 1974.

Michael, J. V., D. F. Nava, R. P. Borkowski, W. A. Payne, and L. J. Stief, Pressure dependence of the absolute rate constant for the reaction $\mathrm{OH}+\mathrm{C}_{2} \mathrm{H}_{2}$ from 228 to $413 \mathrm{~K}, J$. Chem. Phys., 73, 6108-6116, 1980.

Oltmans, S. J., and W. D. Komhyr, Surface ozone distributions and variations from 1973-1984. Measurements at the NOAA Geophysical Monitoring for Climatic Change Baseline Observations, J. Geophys. Res., 91, 5229-5236, 1986.

Polian, G., G. Lambert, B. Ardouin, and A. Jegou, Long-range transport of continental radon in subantarctic and antarctic areas, Tellus, 33B, 178-189, 1986.

Rasmussen, R. A., and M. A. K. Khalil, Latitudinal distributions of trace gases in and above the boundary layer, Chemosphere, 11 , 227-235, 1982.

Routhier, F. R., D. D. Dennett, D. D. Davis, A. Wartburg, P. Haagenson, and A. C. Delany, Free tropospheric and boundarylayer arrborne measurements of ozone over the latitude range of $58^{\circ} \mathrm{S}$ to $70^{\circ} \mathrm{N}, J$. Geophys. Res., 85, 7307-7321, 1980.

Rudolph, J., The two-dimensional distribution of light hydrocarbons, results from the STRATOZ III experiment, J. Geophys. Res., 92, 6653-6661, 1988.

Rudolph, J., and D. H. Ehhalt, Measurements of $\mathrm{C}_{2}-\mathrm{C}_{5}$ hydrocarbons, over the North Atlantic, J. Geophys. Res., 86, 11,959$11,964,1981$.

Rudolph, J., and C. Jebsen, The use of photoionization, flameionIzation and electron capture detection in series for the determination of low molecular weight trace components in the non urban atmosphere, Int. J. Environ. Anal. Chem., 13. 129-139, 1983.

Rudolph, J., D. H. Ehhalt, A. Khedım, and C. Jebsen, Determınation of $C_{2}-C_{5}$ hydrocarbons in the atmosphere at low parts per $10^{9}$ to high parts per $10^{12}$ levels, J. Chromatogr., 217, 301-310, 1981.

Rudolph, J., D. H. Ehhalt, A. Khedim, and C. Jebsen, Latitudinal profiles of some $C_{2}-C_{5}$ hydrocarbons in the clean troposphere over the Atlantic, paper presented at the 2nd Symposium on Composition of the Nonurban Troposphere, Am. Meteorol. Soc., Boston, Mass., 1982.

Rudolph, J., F. J. Johnen, and A. Khedım, Problems connected with the analysis of halocarbons in the non-urban atmosphere, Int. $J$. Environ. Anal. Chem., 27, 97-122, 1986.

Schwerdtfeger, W., The climate of the Antarctic, in Climate of the Polar Regions, World Surv. of Climatol. 14, edted by S. Orvid, pp. 253-329, Elsevier, New York, 1970.

Singh, H. B., and L. J. Salas, Measurement of selected light hydrocarbons over the Pacific Ocean: Latitudinal and seasonal variations, Geophys. Res. Lett., 9, 842-845, 1982.

Tille, K. J. W., M. Savelsberg, and K. Bàchmann, Airborne measurements of nonmethane hydrocarbons over western Europe: Vertical distribution, seasonal cycles of mixing ratios and source strength, Atmos. Environ., 11, 1751-1760, 1985.

Volz, A., D. H. Ehhalt, and R. G. Derwent, Seasonal and latitudinal variation of ${ }^{14} \mathrm{CO}$ and the tropospheric concentration of $\mathrm{OH}$ radicals, J. Geophys. Res., 86, 5163-5171, 1981.

Wagenbach, D., U. Gorlach, K. Moser, and K. O. Munnich, Coastal Antarctic aerosol: The seasonal pattern of its chemical composition and radionuclide content, Tellus $B, 40 B, 426-436$, 1988 .

A. Khedim and J. Rudolph, Institut für Atmosphàrische Chemie, Kernforschungsanlage Julich GmbH, Postfach 1913, D-5170 Jülich, Federal Republic of Germany.

D. Wagenbach, Institut für Unweltphysik, Universität Heidelberg, Im Neuenheimer Feld 366, D-6900 Heidelberg, Federal Republic of Germany.

(Received November 7, 1988; revised April 3, 1989; accepted May 26, 1989.) 